\title{
Effects of The Use of Colored Cover Materials and Led Lighting in Greenhouses on Plant Nutrient Concentration: Case of Tomato Plant (Solanum lycopersicum L.)
}

\author{
Atılgan Atılgan ${ }^{1, a, *}$, İbrahim Erdal ${ }^{2, b}$, Hakan Aktaş,c, Eren Çetin ${ }^{1, d}$ \\ ${ }^{1}$ Department of Agricultural Structures and Irrigation, Faculty of Agriculture, Isparta University of Applied Sciences, 32260 Isparta, Turkey \\ ${ }^{2}$ Department of Soil Science and Plant Nutrition, Faculty of Agriculture, Isparta University of Applied Sciences, 32260, Isparta Turkey \\ ${ }^{3}$ Department of Horticulture, Faculty of Agriculture, Isparta University of Applied Sciences, 32260 Isparta, Turkey \\ *Corresponding author
}

A R T I C E I N F O A B S T R A C T

Research Article

In this study, the effects of four different color plastic greenhouse treatments on nutrient concentrations of leaf and fruit, leaf SPAD (Soil and Plant Analyzer Development) values and some yield parameters of tomato were tried to be determined. For this purpose, plastic greenhouses with Red (RedG), Blue (BlueG), Colorless (ConG) and white Led (LedG) lighting have been used as

Received : 05/06/2020

Accepted : 05/08/2020 materials in the research. The used plastic greenhouses are $3 \mathrm{~m}$ in width, $6 \mathrm{~m}$ in length, $2 \mathrm{~m}$ in sidewall height and $2.8 \mathrm{~m}$ in roof ridge height. Led lighting is; Three hours of extra lighting is planned for one hour before sunrise, 2 hours after sunset. The research was carried out in ISUBU (Isparta), Faculty of Agriculture, field area in the summer season in 2019. The nutrient elements of $\mathrm{K}, \mathrm{Ca}, \mathrm{Mg}, \mathrm{P}, \mathrm{Cu}, \mathrm{Zn}, \mathrm{Mn}$ and Fe were determined in the leaf and of the tomato plant. It has been

Keywords:

Tomato

Greenhouse

Macro and micro elements SPAD

Cover materials determined that four different greenhouse treatments have a positive effect on $\mathrm{K}, \mathrm{Ca}, \mathrm{Cu}, \mathrm{Zn}, \mathrm{Fe}$ nutrients in leaf, and $\mathrm{K}, \mathrm{Ca}, \mathrm{P}, \mathrm{Mg}$ nutrient in fruit. In terms of SPAD values, all treatments were determined to be higher than the control treatment. It was determined that the highest SPAD value was in BlueG treatment. When the efficiency-related values are examined; It was determined that the highest fruit number, fruit weight and yield were in BlueG treatment. BlueG treatment was followed by RedG, ConG, and LedG treatment respectively in terms of efficiency. As a result, considering the effects of four different greenhouse treatments on macro and micronutrient nutritions SPAD values, and yield values, it was concluded that the most suitable treatments for tomato cultivation in greenhouses is BlueG treatment and RedG treatment should not be ignored.

\section{Introduction}

Tomato is a member of the Solanecea family and cultivated for fresh in the open field and protected cultivation as an annual crop. Tomato is a very useful vegetable for human health due to its high content of antioxidant compounds, vitamins, and minerals. For this reason, it is one of the basic vegetables in the world. The world's annual production of tomato is around 163.4 million tones. Tomato production in Turkey ranks $3^{\text {rd }}$ after China and India with 12.8 million tones (FAO, 2019). Tomato quality is influenced by genetic and environmental factors such as climatic conditions; temperature, humidity, light (Dumas et al., 2003; Caliman et al., 2010), beside cultural practices such as purring, nutrient concentration, and frequency of irrigation, harvesting method, maturity stage at harvest (Kader, 1986; Aktas et al., 2009; Ergun and Aktas, 2018; Ildir and Aktas, 2018) and postharvest handling (Dorais et al., 2001). Tomato production in protected cultivation has expanded to prevent seasonality in the availability of fruit (Andriolo et al., 1998). Alterations in light intensity, temperature, and relative humidity occur in protected cultivation and can affect the production and the partitioning of photo-assimilates in the plant and, consequently, the composition of the produced tomato fruit (Ildir and Aktas, 2018).

Light quality and light sources with respect to the plants have a significant impact on product yield. In addition to the light source and quality, it acts in light spectrum colors on plant growth (Massa et al., 2008). It has been put forth in various studies that the blue and red-light spectrum is the best for photosynthesis (Tunçbilek, 2019).

Chlorophyll reflects the majority of the green wavelengths and does not use them in photosynthesis. 
Therefore, plants absorb purple-blue and red-light waves more and use them in photosynthesis (Büyük 2018; Tunçbilek, 2019). Plant growth can adaptive to the light environment; characteristics such as extension growth, architecture, and leaf morphology change, depending on the light spectrum. Although blue (B; 400-500 nm) and red (R; 600-700 nm) light are generally considered the most efficient wavelengths for eliciting photosynthesis, both are often required for relatively normal growth (Wollaeger and Runkle, 2015).

The aim of this work was to study the tomato mineral nutrition from different colors (red and blue) and Led lighting under plastic greenhouses during the summer season growing.

\section{Material and methods}

Tomato (Solanum lycopersicum, cv. 'Torry') was tested in simple plastic greenhouses. The study was carried out in different color plastic greenhouses in the field areas of Isparta University of Applied Sciences, Faculty of Agriculture. The study was completed in the summer production season of 2019. The plastic greenhouses are 3 $\mathrm{m}$ in width, $6 \mathrm{~m}$ in length, $2 \mathrm{~m}$ in sidewall height and 2.8 $\mathrm{m}$ in roof ridge height. For this purpose, plastic greenhouses with Red (RedG), Blue (BlueG), Colorless (ConG) and White Led (LedG) lighting have been used as covered materials in the research. Red and blue cover materials were sprayed with powder paint and all sides of the greenhouse were painted equally. Led lighting is; Three hours of extra lighting is planned for one hour before sunrise, 2 hours after sunset. As a result of these treatments, the effects of four different greenhouse treatments on macro and micronutrient uptake, SPAD values and yield values were tried to be determined. In the study, irrigation, fertilizer application and maintenance facilities of four different greenhouse treatments were carried out equally. During the experiment, the fertilization dosages at the concentrations below were applied to the plants.

Fertilizer and stock solution concentration; 0-3 / 3-8 cluster stage (mg / L): N: 150/200; K: 200/300; P: 50/60; Mg: 50/60; Ca: 120/150; Fe: 5.0 / 5.0; Mn: 2.0 / 2.0; Zn: from 0.25 / 0.25; B: $0.70 / 0.70$; Mo: $0.05 / 0.05$. The electrical conductivity $(\mathrm{EC}, \mathrm{ds} / \mathrm{m})$ is set to $1.5-2.0$ and 2.0 3.0 at $0-3$ and $3-8$ cluster stages, respectively. The $\mathrm{pH}$ was arranged around 5.5-6.0 by nitric acid. All the nutrient was given by drip irrigation (Ildir and Aktas, 2018). Some properties of the soils used for the experiments and related references were given in Table 1.

In order to determine leaf nutrient concentrations samples were taken from the 5th or 6th leaves from the top (Geraldson et al., 1973). Sampling was made from all sides of the plant. In addition, fruit sampling was made to represent each greenhouse from the fruits that have reached harvesting maturity. All samples were washed thoroughly with tap water, dilute acid $(0.2 \mathrm{~N} \mathrm{HCl})$ and distilled water to remove surface residues. Leaves and thinly sliced fruits were put in air flow oven at $65 \pm 5^{\circ} \mathrm{C}$ until stable weight. Finally, they were grinded to digestion. All plant samples were wet digested and nutrient concentrations were measured using atomic absorption spectrophotometer (Jones et al., 1991).

Leaf greenness (SPAD value) was measured using Minolta-502 SPAD meter. For this, ten readings were made from the different leaves of 3rd and 4th blades each reading is the average of 4 reading values obtained from the same leaf. Means of 10 readings were accepted as a replication. Statistical evaluations of the results were made using MSTAT program. Differences between means were compared using Duncans' multiple range tests.

Table 1. Some characteristics of the soil used for the experiment

\begin{tabular}{l|cc}
\hline \multicolumn{1}{c|}{ Properties } & Value & References \\
\hline Organic matter $(\%)$ & 1.8 & (Walkley and Black, 1934) \\
$\mathrm{CaCO}_{3}(\%)$ & 18 & (Allison and Moodie, 1965) \\
Texture & $\mathrm{CL}$ & (Bouyoucos, 1951) \\
$\mathrm{pH}(1 / 2 \mathrm{soil} /$ water) & 7.5 & (Kacar, 2009). \\
Available P $\left(\mathrm{mg} \mathrm{kg}^{-1}\right)$ & 30 & (Olsen et al, 1954) \\
\hline Exchangeable Ca $\left(\mathrm{cmol} \mathrm{kg}^{-1}\right)$ & 30 & \\
Exchangeable K $\left(\mathrm{cmol} \mathrm{kg}^{-1}\right)$ & 4.0 & \\
Exchangeable $\mathrm{Mg}\left(\mathrm{cmol} \mathrm{kg}^{-1}\right)$ & 3 & (Lindsay and Norvell, 1969) \\
\hline DPTA Extractable Fe $\left(\mathrm{mg} \mathrm{kg}^{-1}\right)$ & 10 & \\
DPTA Extractable Mn $\left(\mathrm{mg} \mathrm{kg}^{-1}\right)$ & 30 & \\
DPTA Extractable Zn $\left(\mathrm{mg} \mathrm{kg}^{-1}\right)$ & 2.5 & 5 \\
DPTA Extractable Cu $\left(\mathrm{mg} \mathrm{kg}^{-1}\right)$ & & \\
\hline
\end{tabular}

\section{Results and Discussions}

The effects of LED lighting and colored coverage materials on some macro and micronutrient concentrations in the leaves and fruits of tomato plants grown in greenhouse conditions were determined.

Leaf $\mathrm{K}$ and $\mathrm{Ca}$ concentrations were indicated in Figure 1. Although, there is not a significant difference $(\mathrm{P}>0.05)$ between the values from each treatment, the highest $\mathrm{K}$ values $(2.4 \%)$ in the leaves were obtained from both RedG and LedG followed by ConG and BlueG.
According to Campbell (2000) and Jones et al 1991, leaf $\mathrm{K}$ levels were below the critical concentration. Potassium has many functions on plant metabolism. So, it plays vitally roles on plant growth and yield. Also, researchers stated that potassium is not only effective on growth, development and metabolic properties, but also against diseases, frosts, and pests (Marschner, 2011). Leaf Ca concentrations measured from the RedG and LedG treatments were higher than those measured from other treatments. Leaf $\mathrm{Ca}$ concentration measured from the 
RedG treatment was found to be significantly different from the others $(\mathrm{P}<0.01)$. All values were over the critical levels indicated for tomato (Jones, 1991; Campbell, 2000). Leaf $\mathrm{P}$ and $\mathrm{Mg}$ concentrations were given in Figure 2. In terms of $\mathrm{P}$, there were not significant differences between the treatments, but it was seen that $\mathrm{P}$ concentration under RedG treatment was lower $(0.6 \%)$ than others. All values were between or over the sufficiency ranges (Jones et al., 1991; Campbell, 2000).

No significant differences were found between the applications in terms of leaf $\mathrm{Mg}$ concentrations (Figure. 2). But leaf $\mathrm{Mg}$ concentrations measured from the BlueG was below $(0.2 \%)$ whereas the others are between the sufficiency ranges (Jones et al., 1991). Magnesium plays many roles in plant physiology. For example; magnesium is a central element in chlorophyll molecules (Marschner, 2011). Fruit $\mathrm{K}$ and $\mathrm{Ca}$ concentrations were given in Figure 3. Looking at the results it can be seen that the highest $\mathrm{K}(3 \%)$ in fruit was found from the BlueG treatment whereas the lowest $(2.7 \%)$ was obtained ConG applications. But differences between the treatments were not significant for K.

Fruit Ca concentrations varied between $0.46 \%$ (BlueG) and $0.32 \%$ (RedG). But these variations were not statistically significant. Fruit $\mathrm{Ca}$ concentrations indicated here above the critical level $(1.5 \%)$ resulting in blossom and root (Jones, 1999). Fruits under LedG treatment had the highest $\mathrm{P}$ concentration $(0.63 \%)$ followed by RedG, ConG and BlueG treatments (Figure 4). The results for fruit $\mathrm{P}$ concentration are in agreement with the results of study conducted by Ceylan et al. (2001). Although fruit $\mathrm{Mg}$ concentrations varied between 0.09 and $0.1 \%$, these variations were not significant (Figure 4). LedG application for fruit $\mathrm{P}$ concentration and BlueG application for fruit $\mathrm{Mg}$ concentrations seem to be more efficient.

Leaf $\mathrm{Cu}$ concentrations of tomato grown under different color coverage materials and led lightning were between 18.6 (RedG) and $16.93 \mathrm{mg} \mathrm{kg}^{-1}$ (ConG) and these variations were significant (Figure 5). The values obtained from each treatment were between the limit value $(5-50 \mathrm{mg}$ $\mathrm{kg}^{-1}$ ) indicated by Jones et al (1991) and Campbell (2000). Treatments significantly affected leaf $\mathrm{Zn}$ concentrations. As indicated in Figure 5, the highest $\mathrm{Zn}$ was measured from the leaves obtained from LedG treatment as $18.05 \mathrm{mg} \mathrm{kg}^{-1}$ but the lowest was measured from BlueG treatment as $14.45 \mathrm{mg} \mathrm{kg}^{-1}$. According to the sufficiency ranges (18-80 $\mathrm{mg} \mathrm{kg}{ }^{-1}$ ) indicated by Campbell (2000), only the value obtained from LedG was in this range. Zinc deficiency gives rise to too many effects such as growth delay, stunted growth, infertility, maturity delay, loss of yield, etc. (Bergman, 1999). RedG for leaf $\mathrm{Cu}$ and $\mathrm{LedG}$ for $\mathrm{Zn}$ can be said more favorable.

Leaf $\mathrm{Mn}$ and $\mathrm{Fe}$ concentrations have given in Figure 6. The highest leaf Mn concentrations were found at ConG treatment (149.9 $\left.\mathrm{mg} \mathrm{kg}^{-1}\right)$ but the lowest was found at BlueG treatment $\left(123.97 \mathrm{mg} \mathrm{kg}^{-1}\right)$. All $\mathrm{Mn}$ the values were in the sufficiency ranges (Jones et al., 1991; Campbell, 2000). According to the statistical evaluation values from ConG and LedG values from RedG and BlueG were significantly different $(\mathrm{p}<0.01)$. Leaf Fe concentrations were between $62.17 \mathrm{mg} \mathrm{kg}^{-1}$ (ConG) and $92.37 \mathrm{mg} \mathrm{kg}^{-1}$ (BlueG). All these values were sufficient for tomato growth (Jones et al., 1991; Campbell, 2000). Leaf $\mathrm{Fe}$ values measured from each treatment significantly varied from each other.
Fruit $\mathrm{Cu}$ and $\mathrm{Zn}$ concentrations have been given in Figure 7. As indicated there, $\mathrm{Cu}$ and $\mathrm{Zn}$ concentrations in fruits varied from 3.8 (RedG) to $5.5 \mathrm{mg} \mathrm{kg}^{-1}$ (ConG) and 11 . 6 (RedG) to $14 \mathrm{mg} \mathrm{kg}^{-1}$ (ConG), respectively. While differences in $\mathrm{Cu}$ between $\mathrm{ConG}$ and RedG were significant, differences in $\mathrm{Zn}$ between the treatments were not.

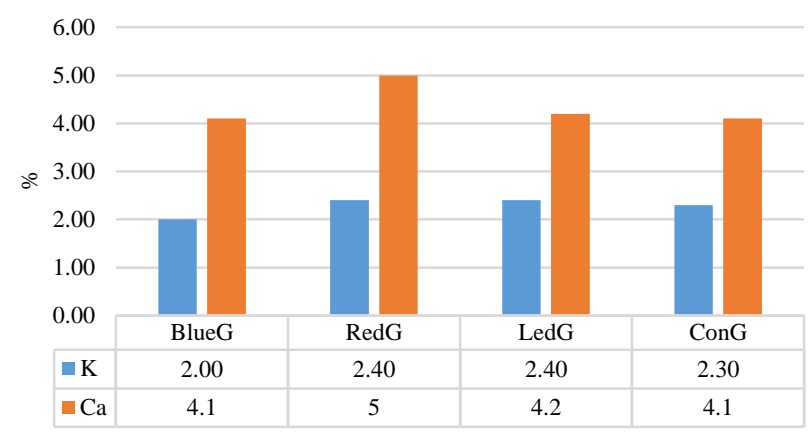

Figure 1. Leaf $\mathrm{K}$ and $\mathrm{Ca}$ variations of tomato plant under different cover material and Led lighting

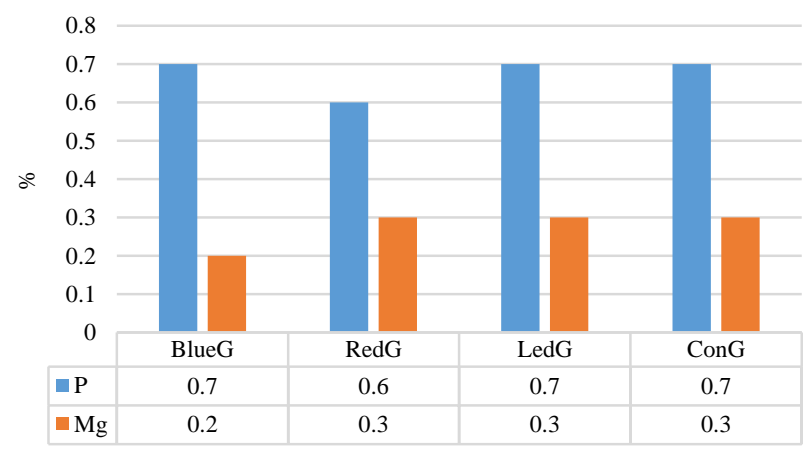

Figure 2. Leaf $\mathrm{P}$ and $\mathrm{Mg}$ variations of tomato plant under different cover material and Led lighting

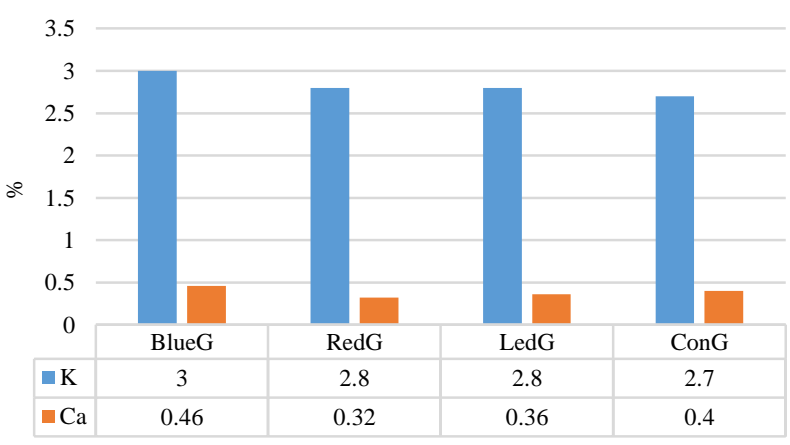

Figure 3. Fruit $\mathrm{K}$ and $\mathrm{Ca}$ variations of tomato plant under different cover material and Led lighting

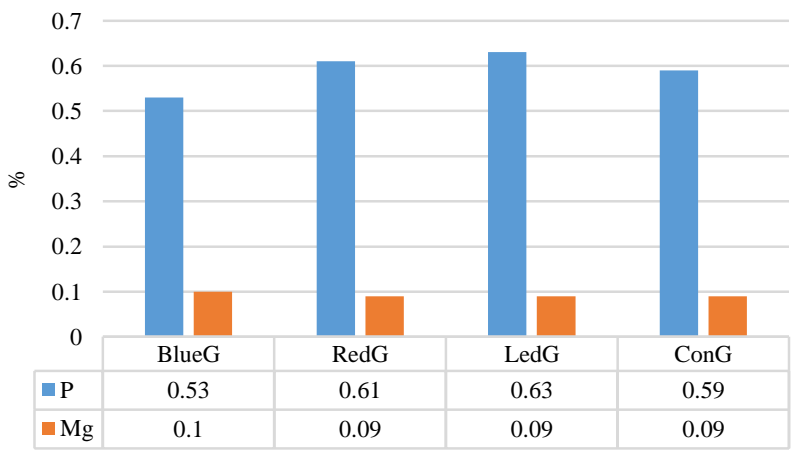

Figure 4. Fruit $\mathrm{P}$ and $\mathrm{Mg}$ variations of tomato plant under colored cover material and Led lighting 


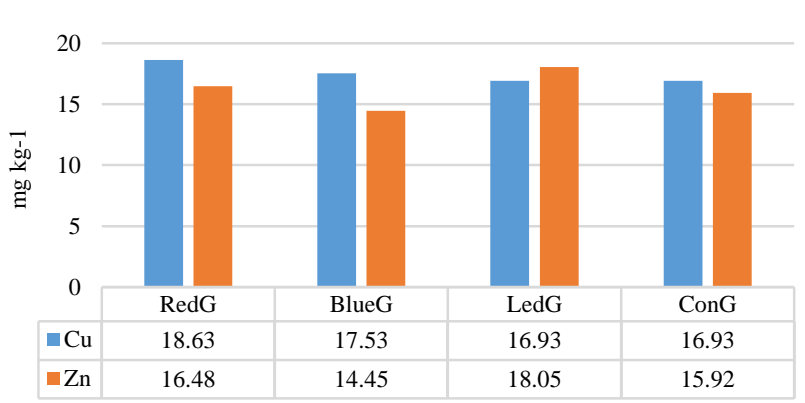

Figure 5. Leaf $\mathrm{Cu}$ and $\mathrm{Zn}$ variations depending on colored cover material and Led lighting

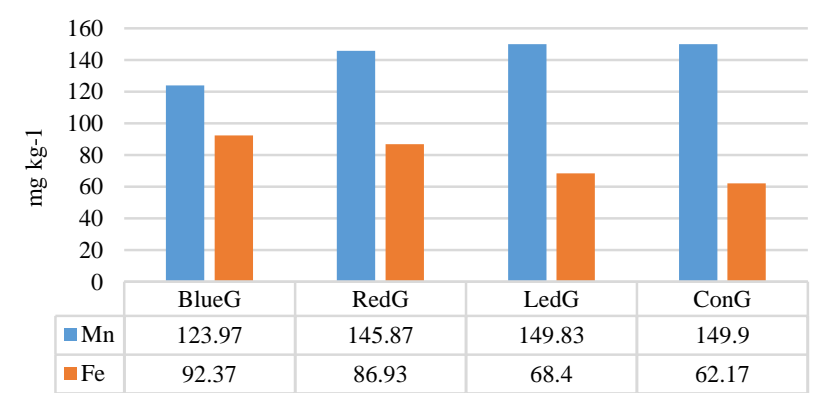

Figure 6. Leaf Mn and Fe variations depending on colored cover material and Led lighting

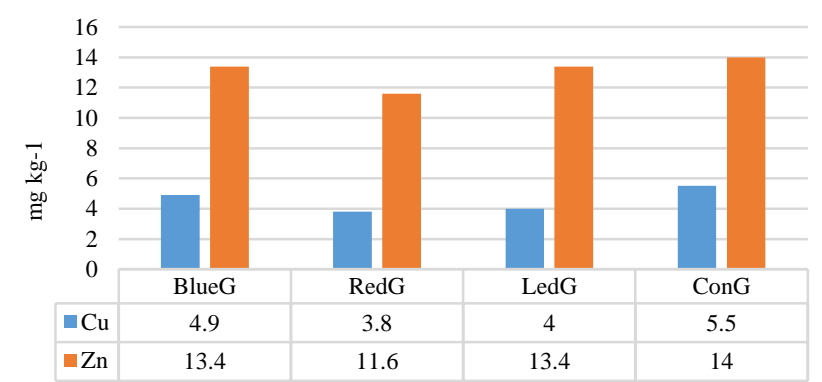

Figure 7. Fruit $\mathrm{Cu}$ and $\mathrm{Zn}$ variations depending on colored cover material and Led lighting

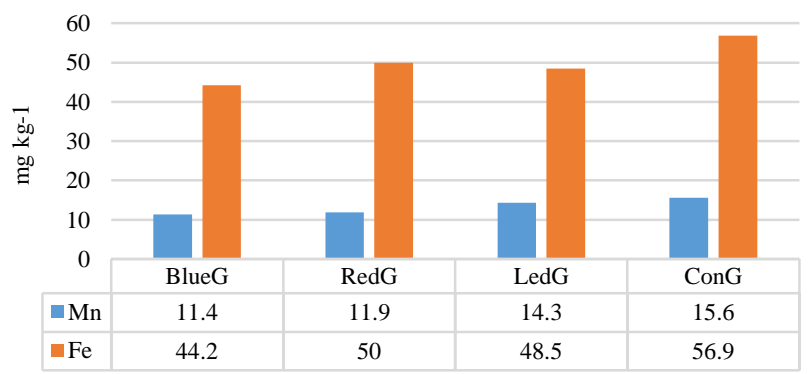

Figure 8. Fruit $\mathrm{Mn}$ and $\mathrm{Fe}$ variations depending on colored cover material and Led lighting

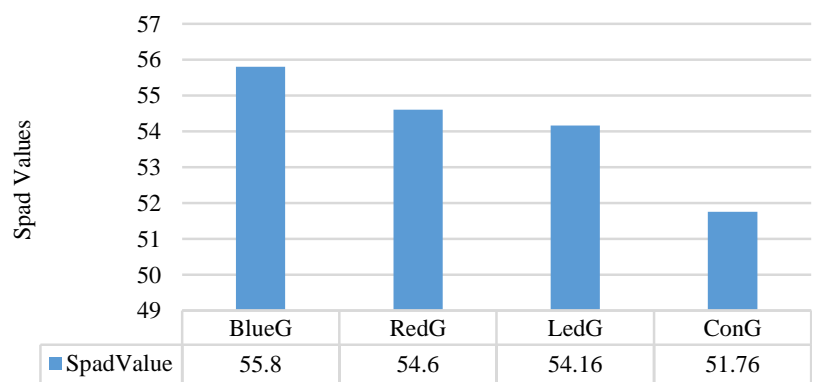

Figure 9. SPAD values in four different applications used in the research
Fruit Mn concentrations significantly changed between 11.4 and $15.6 \mathrm{mg} \mathrm{kg}^{-1}$ (Figure 8). As in Mn, the highest Fe concentration was determined from ConG treatment as $56.9 \mathrm{mg} \mathrm{kg}^{-1}$ and the lowest was determined from BlueG treatment as $44.2 \mathrm{mg} \mathrm{kg}^{-1}$. Treatments did not affect fruit Fe significantly $(\mathrm{P}>0.05)$. Results indicated that color treatment and Led lighting did not increase fruit micro element concentrations.

Leaf greenness (SPAD value) increased slightly with Led lighting and colored material applications when compared to control (ConG). And differences between BlueG and ConG were significant (Figure 9). According to Öztürk (2008), it was reported that the light color that chlorophyll absorbs the most is blue and red. Therefore, it can be said that chlorophyll development is higher in BlueG and RedG treatments compared to other treatments.

Looking at the yield and yield parameters it was seen that the highest yield, fruit number, and fruit weight were obtained from BlueG treatment. BlueG treatments were followed by RedG, ConG and LedG treatments in terms of yield (Table 2). When nutrient concentrations, yield parameters, and SPAD values are taken into consideration, it has been determined that BlueG and RedG applications are prominent in four treatments for tomato plants. In our study, it was determined that the yield and SPAD values were high under red and blue color (Figure 9 and Table 2). This situation can be explained by the increase in leaf chlorophyll content meanly leaf green coloration (Erdal et al., 2016), which causes the increase of photosynthesis activity, and accordingly the high amount of $\mathrm{CO}_{2}$ taken into the plant. Lui et al. (2011), in their color study, it was determined that B (Blue), RB (Red-Blue) and RBG (RedBlue-Green) color treatment increased the length of leaf mesophyll tissue cells and chloroplast development in cherry tomato. They also stated that the treatment of Red and Blue color increased their stoma diameters, and the treatment of Blue increased the rate of photosynthesis. Öztürk (2008) stated that the most reaction for plant development and photosynthesis occurred in red and blue light. These studies support our findings.

Most greenhouse cultivation in Turkey is carried out in the Mediterranean and Aegean regions. In the observations we obtained in these regions, shading dust (white) treatment is widely used for shading in both plastic and glass greenhouses (Figure 10). It is also seen that they use a green plastic net for shading. However, the treatment in blue or red color for shading is almost not seen. The pictures of the blue and red color treatment in our study are given in Figure 11.

\section{Conclusions}

In the research, $\mathrm{K}, \mathrm{Ca}, \mathrm{P}$ and $\mathrm{Mg}$ macronutrient contents and $\mathrm{Cu}, \mathrm{Zn}, \mathrm{Mn}$ and $\mathrm{Fe}$ micronutrient content in the leaf and fruit content of tomato plants of four different treatments were determined. It has been determined that the use of different color cover materials and Led lighting has a positive effect on the nutrients of $\mathrm{K}, \mathrm{Ca}, \mathrm{Cu}, \mathrm{Zn}$ and $\mathrm{Fe}$ in leaf contents and $\mathrm{K}, \mathrm{Ca}, \mathrm{P}, \mathrm{Mg}$ in fruit contents. In terms of the nutritional elements of the tomato plant, we can say that RedG treatment in the leaf and BlueG treatment in fruit contents is more suitable. At the same time, SPAD values of tomato plants were determined. The 
highest value in terms of SPAD values was realized in BlueG treatment. Also, SPAD values of all treatments were found higher than ConG treatment. In addition, considering the yield values of the tomato plant, the highest yield values were in BlueG treatment, followed by RedG, ConG and LedG treatments, respectively. Sometimes results that are not statistically significant can be important in practice.
As a result, considering the effects of four different greenhouse treatments on macro and micronutrient intake, SPAD values and yield values, it was concluded that the most suitable application for tomato cultivation in greenhouses is BlueG application and RedG application should not be ignored.

Table 2. Effects of four different treatments on yield

\begin{tabular}{l|ccc}
\hline \multicolumn{1}{c}{ Plastic color } & Fruit number/ per 30 plants & Average fruit weight $(\mathrm{gr})$ & Total yield $(\mathrm{kg} / \mathrm{da})$ \\
\hline BlueG & 746 & 180 & 7.58 \\
RedG & 544 & 180 & 5.39 \\
ConG & 594 & 140 & 4.66 \\
LedG & 540 & 150 & 4.48 \\
\hline
\end{tabular}
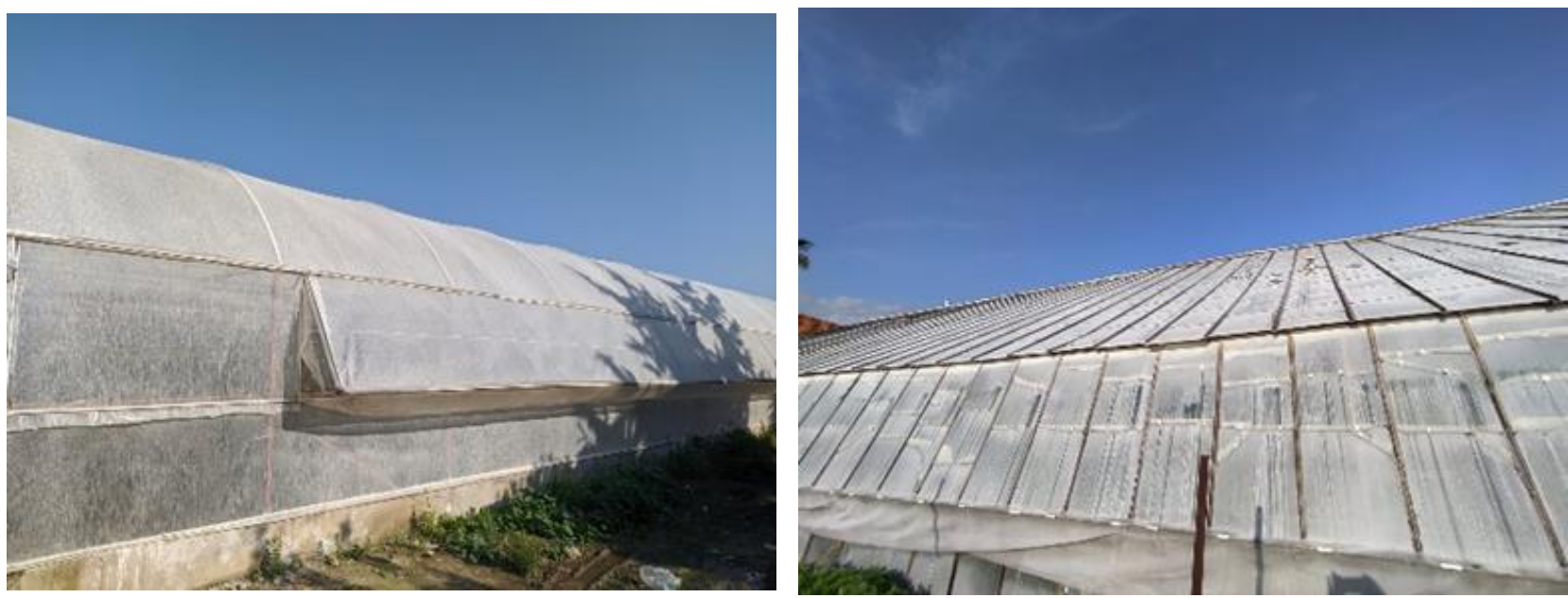

Figure 10. Shading dust (white) treatment in plastic and glass greenhouses (Antalya, Turkey)
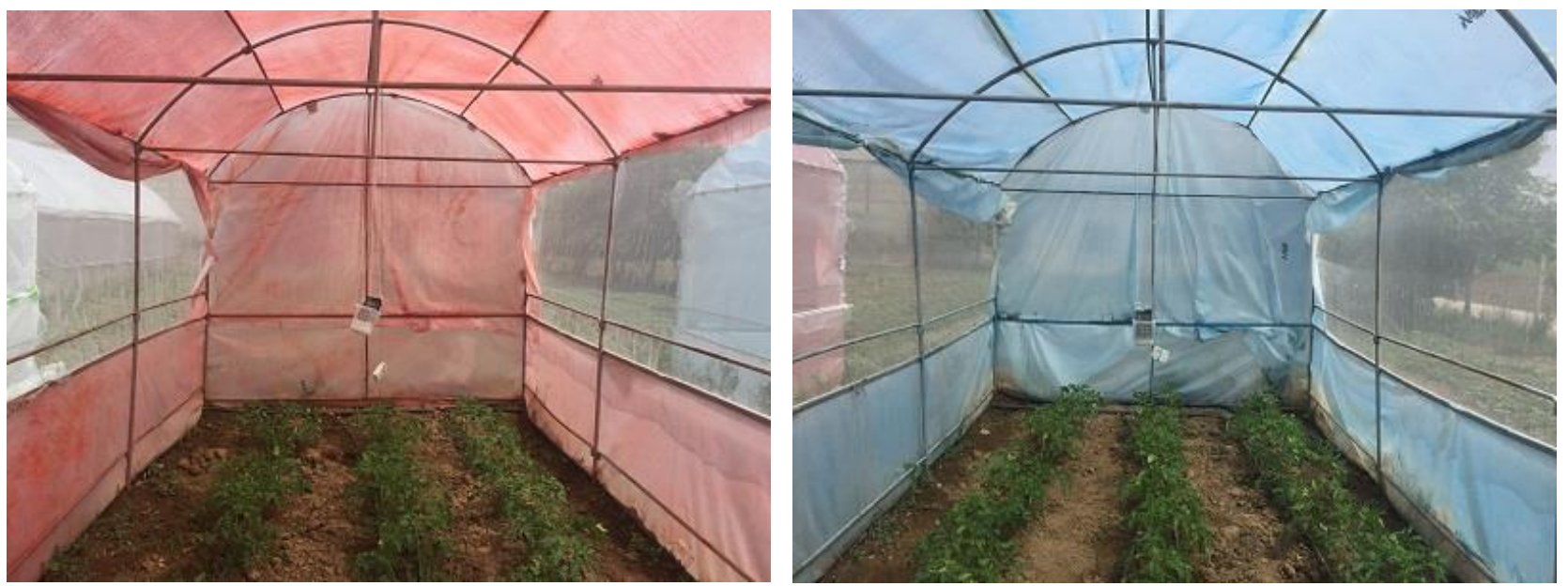

Figure 11. The pictures of the red and blue color treatment in plastic greenhouses

\section{References}

Aktas H, Söylemez S, Pakyurek AY, 2009. Effect of different pruning systems on bell pepper (Capsicum annuum 1.) growing in greenhouse. Journal of the Faculty of Agriculture of Harran University 13(3): 31-36.

Allison LE, Moodie CD. 1965. Carbonate. In: C.A. Black et al (ed.) Methods of soil analysis. Part 2. Agronomy 9: 1379-1400. American Society of Agronomy Inc. Madison, Wisconsin. USA. Andriolo JL, Streck NA, Buriol GA, Ludke L, Duarte TS. 1998. Growth, development and dry matter distribution of a tomato crop as affected by environment. Journal of Horticultural Science and Biotechnology 73: 125-130.
Bergmann W, 1999. Nutritional Disorders of Plants: Development, Visual and Analytical Diagnosis, Spektrum Akademischer Verlag, pp741.

Bouyoucos GL. 1951. A Recalibration of the hydrometer for making mechanical analysis of soil, Agronomy journal 43(9):434-438.

Caliman FRB, da Silva, DJH, Stringheta PC, Fontes, PCR, Moreira. GR, Mantovani EC. 2010. Quality of tomatoes grown under a protected environment and field conditions. Idesia (Chile) 28:75-82. 
Campbell CR. 2000. Reference sufficiency ranges for plant analysis in the southern region of the US. Southern cooperative series bulletin 394, updated and reformatted July 2009 http://www.clemson.edu/ sera6/scsb394notoc.pdf

Ceylan Ş, Mordoğan N, Yoldaş F, Yağmur, B. 2001. Azotlu gübrelemenin domates bitkisinde verim, azot birikimi ve besin element içeriği üzerine etkisi. Ege Üniversitesi Ziraat Fakültesi Dergisi, 38(2-3):103-110.

Dorais M. Papadopoulos, AP, Gosselin A. 2001. Greenhouse tomato fruit quality. Horticultural Reviews. 26: 239-319.

Dumas Y, Dadomo M, Di Lucca G, Grolier P. 2003. Effects of environmental factors and agricultural techniques on antioxidant content of tomatoes. Journal of the Science of Food and Agriculture 83:369-382.

Erdal Í, Türkmen R, Akgün A. 2016. Variations in chlorophyll, SPAD values and some nutrient concentrations depending on chlorosis in peach leaves. Lucrări Ştiinţifice, 59:13-16.

Ergun V, Aktas H. 2018. Effect of grafting on yield and fruit quality of pepper (Capsicum annuum) grown under open field conditions. Scientific Papers. Series B, Horticulture. Vol. LXII:463-466.

Ildir İ, Aktas H. 2018. Effect of Different Type of Pruning on the Yield and Quality of Greenhouse Tomato Production. Süleyman Demirel University, Journal of Natural and Applied Sciences. 22(3):1241-1248

Jackson ML. 1967. Soil chemical analysis. Prentice Hall of India Private Limited. New Delhi.

Jones Jr JB, Wolf B, Mills, HA. 1991. Plant Analysis Handbook. A Practical Sampling, Preparation, Analysis, and Interpretation Guide, Micro-Macro Publishing, Inc: Athens, GA.

Jones Jr JB. 1999. Tomato Plant Culture, In the Field, Greenhouse, and Home Garden, USA, 199 pp.
Kacar B. 2009. Soil analysis. Nobel Press. 1387.

Kader AA. 1986. Effects of postharvest handling procedures on tomato quality. Acta Horticulturae. 190:209-221.

Lindsay WL, Norvell WA. 1969. Development of a DTPA micronutrient soil test. Soil Science Society of American Proceeding 35:600-602.

Liu XY, Guo SR, Xu ZG, Jiao XL, Takafumi T. 2011. Regulation of Chloroplast Ultrastructure, Cross-Section Anatomy of Leaves, and Morphology of Stomata of Cherry Tomato by Different Light Irradiations of Light-Emitting Diodes, HortScience, 46:217-221.

Marschner H. 2011. Marschner's mineral nutrition of higher plants. Academic press, 2011.

Massa GD, Kim HH, Wheeler RM, Mitchell CA. 2008. Plant productivity in response to LED lighting. HortScience 43:1951-1956.

Olsen A. 1954. Estimation of available phosphorus in soils by extraction with sodium bicarbonate. Us Dep. of Agri. Circ. 939. Washington DC. Agronomy Journal 43: 434-437.

Öztürk HH. 2008. Sera İklimlendirme Tekniği. Hasad Yayıncılık Ltd. Şti., 305s. İstanbul.

Walkley A, Black IA. 1934. An examination of the degtjareff method for determining soil organic matter and a proposed modification of the chromic acid titration method, Soil Science 37(1): 29-38.

Wollaeger HM., Runkle ES, 2015. Growth and Acclimation of Impatiens, Salvia, Petunia, and Tomato Seedlings to Blue and Red Light, Hortscience 50(4): 522-529.

Tunçbilek F. 2019. Sera Yetiştiriciliğinde Farklı Renklerdeki Örtü Malzemelerinin Gelişim Üzerine Etkileri: Marul Örneği, YL Tezi, Isparta Uygulamalı Bilimler Üniversitesi, Lisansüstü Eğitim Enstitüsü, Isparta. 